\title{
Muscarinic Receptor Sequestration in SH-SY5Y Neuroblastoma Cells Is Inhibited when Clathrin Distribution Is Perturbed
}

\author{
$*+$ Diana M. Slowiejko, *Edward L. McEwen, $¥$ Stephen A. Ernst, and $* \dagger$ Stephen K. Fisher \\ * Neuroscience Laboratory, Mental Health Research Institute; and Departments of $\dagger$ Pharmacology and $\ddagger$ Anatomy \\ and Cell Biology, University of Michigan, Ann Arbor, Michigan, U.S.A.
}

\begin{abstract}
The possibility that clathrin plays a role in the agonist-mediated sequestration of muscarinic cholinergic receptors in human SH-SY5Y neuroblastoma cells has been investigated by the application of experimental paradigms previously established to perturb clathrin distribution and receptor cycling events. Preincubation of $\mathrm{SH}-$ SY5Y cells under hypertonic conditions resulted in a pronounced inhibition of agonist-induced muscarinic receptor sequestration $(70-80 \%$ at $550 \mathrm{mOsm})$, which was reversed when cells were returned to isotonic medium. Depletion of intracellular $\mathrm{K}^{+}$or acidification of the cytosol also resulted in $>80 \%$ inhibition of muscarinic receptor sequestration. Under conditions of hypertonicity, depletion of intracellular $\mathrm{K}^{+}$, or acidification of cytosol, muscarinic receptor-stimulated phosphoinositide hydrolysis and $\mathrm{Ca}^{2+}$ signaling events were either unaffected or markedly less inhibited than receptor sequestration. That these same experimental conditions did perturb clathrin distribution was verified by immunofluorescence studies. Hypertonicity and depletion of intracellular $\mathrm{K}^{+}$resulted in a pronounced accumulation of clathrin in the perinuclear region, whereas acidification of the cytosol resulted in the appearance of microaggregates of clathrin throughout the cytoplasm and at the plasma membrane. The results are consistent with the possibility that muscarinic receptors in SH-SY5Y cells are endocytosed via a clathrindependent mechanism. Key Words: Phosphoinositide hydrolysis - $\mathrm{Ca}^{2+}$ signaling-Caveolae-Hyperosmolarity-Depletion of intracellular $\mathrm{K}^{+}$- Receptor endocytosis.

J. Neurochem. 66, 186-196 (1996).
\end{abstract}

Prolonged agonist occupancy of either adenylyl cyclase or phosphoinositide-specific phospholipase C (PLC)-linked receptors results in an adaptive response in which cell surface receptors are internalized (sequestered) and thereby become less accessible to hydrophilic ligands. Although receptor sequestration has been frequently documented, neither the underlying molecular events nor the precise physiological significance has been established. In the latter context, several possibilities exist, such as uncoupling of the recep- tor from effector enzyme (Thompson and Fisher, 1991; Fisher, 1995), dephosphorylation of cell surface receptors ( Yu et al., 1993), or an obligatory precursor event in receptor down-regulation (Thompson and Fisher, 1990; but see also Hausdorff et al., 1990). Furthermore, there has been some controversy as to whether sequestered receptors are truly endocytosed into a cytoplasmic compartment, as indicated from studies of the agonist-induced subcellular redistribution of receptors (Harden et al., 1985), or whether changes in radioligand binding reflect more an altered conformation of the receptor within the same plasma membrane location (Wang et al., 1989). The recent immunocytochemical demonstration of $\beta_{2}$-adrenergic receptors localized to intracellular vesicles following agonist addition favors the hypothesis that cell surface receptors undergo endocytosis (vonZastrow and Kobilka, 1992). Evidence for a colocalization of the internalized $\beta_{2^{-}}$ adrenergic receptor with the transferrin receptor (which is endocytosed via a clathrin-coated pit mechanism) has been obtained from immunocytochemical studies (vonZastrow and Kobilka, 1992). However, whether the endocytosed $\beta_{2}$-adrenergic receptors originate in clathrin-coated pits or, alternatively, in nonclathrin-coated membrane invaginations, e.g., caveolae ( see Anderson, 1993), remains uncertain. In addition, there is currently little mechanistic information regard-

Received April 3, 1995; revised manuscript received July 17 , 1995; accepted July 28, 1995.

Address correspondence and reprint requests to Dr. S. K. Fisher at Neuroscience Laboratory, Mental Health Research Institute, University of Michigan, 1103 East Huron Street, Ann Arbor, MI 481041687, U.S.A.

Abbreviations used: BCECF-AM, 2,7-biscarboxyethyl-5(6)-carboxyfluorescein acetoxymethyl ester; $\left[\mathrm{Ca}^{2+}\right]_{i}$, cytoplasmic $\mathrm{Ca}^{2+}$ concentration; $I(1,4,5) \mathrm{P}_{3}$, inositol 1,4,5-trisphosphate; $I \mathrm{P}_{\mathrm{T}}$, total inositol phosphate fraction; $\mathrm{K}^{+}{ }_{i}$, intracellular $\mathrm{K}^{+} ; \mathrm{mAChR}$, muscarinic cholinergic receptor; NMS, $N$-methylscopolamine; Oxo-M, oxotremorine-M; PBS, phosphate-buffered saline; PLC, phosphoinositide-specific phospholipase C; PMA, phorbol 12-myristate 13-acetate; QNB, quinuclidinyl benzilate. 
ing the endocytosis of other $\mathrm{G}$ protein-coupled receptors, in particular those linked to PLC.

In the present study, biochemical and immunocytochemical approaches have been used to evaluate the role, if any, played by clathrin in the agonist-mediated sequestration of muscarinic cholinergic receptors (mAChRs) present in human SH-SY5Y neuroblastoma. These cells have been previously demonstrated to express a relatively high density of $\mathrm{mAChRs}$ (20,000-30,000 per cell) that are predominantly ( $\sim 80 \%$ ) of the $\mathrm{m}_{3}$ subtype and that couple to phosphoinositide turnover (Slowiejko et al., 1994). Moreover, the presence of clathrin has been documented in these cells (Sadée et al., 1987). The present results indicate that experimental procedures that have previously been demonstrated to perturb clathrin distribution and to inhibit receptor endocytosis via either the disruption of formation of clathrin-coated pits, e.g., hypertonicity or depletion of intracellular $\mathrm{K}^{+}\left(\mathrm{K}^{+}{ }_{\mathrm{i}}\right)$ (Larkin et al., 1986; Heuser and Anderson, 1989) or, alternatively, by prevention of the budding of coated pits, e.g., acidification of the cytosol (Sandvig et al., 1987), all result in a marked inhibition of agonist-mediated mAChR sequestration in SH-SY5Y cells. However, the ability of mAChRs to couple to PLC and second messenger generation in SH-SY5Y cells is much less adversely affected by these procedures. Immunocytochemical studies indicate that a cellular redistribution of clathrin accompanies the observed attenuation of $\mathrm{mAChR}$ sequestration. The results suggest that upon agonist addition, mAChRs in SH-SY5Y cells are endocytosed via a clathrin-linked mechanism. A preliminary account of part of this work has previously been reported (Slowiejko et al., 1995).

\section{MATERIALS AND METHODS}

myo- $\left[2-{ }^{3} \mathrm{H}\right]$ Inositol $(102 \mathrm{Ci} / \mathrm{mmol}),\left[N\right.$-methyl $\left.-{ }^{3} \mathrm{H}\right]-$ scopolamine methyl chloride ([ $\left.\left.{ }^{3} \mathrm{H}\right] \mathrm{NMS} ; 87 \mathrm{Ci} / \mathrm{mmol}\right)$, $\left[{ }^{3} \mathrm{H}\right]$ inositol $1,4,5$-trisphosphate $\left\{\left[{ }^{3} \mathrm{H}\right] \mathrm{I}(1,4,5) \mathrm{P}_{3} ; 15 \mathrm{Ci} /\right.$ $\mathrm{mmol}\}$, and $\left[{ }^{3} \mathrm{H}\right]$ scopolamine $(74.9 \mathrm{Ci} / \mathrm{mmol})$ were purchased from Amersham Corp. (Arlington Heights, IL, U.S.A.). $\left[{ }^{3} \mathrm{H}\right]$ Quinuclidinyl benzilate $\left(\left[{ }^{3} \mathrm{H}\right] \mathrm{QNB} ; 45.4 \mathrm{Ci} /\right.$ mmol) was obtained from New England Nuclear (Boston, MA, U.S.A.). Atropine, pilocarpine, NMS, phorbol 12-myristate 13-acetate (PMA), digitonin, filipin, nigericin, and nystatin were obtained from Sigma Chemical Co. (St. Louis, MO, U.S.A.). Oxotremorine-M (Oxo-M) was purchased from Research Biochemicals International (Natick, MA, U.S.A.). Fura-2 acetoxymethyl ester, 2,7-biscarboxyethyl5(6)-carboxyfluorescein acetoxymethyl ester (BCECF$A M)$, and anti-fluorescein rabbit IgG were obtained from Molecular Probes (Eugene, OR, U.S.A.). $\mathbf{I}(1,4,5) \mathrm{P}_{3}$ and concanavalin A were purchased from Calbiochem (San Diego, CA, U.S.A.) . Pepstatin, leupeptin, aprotinin, and Pefabloc [4-(2-aminoethyl)-benzenesulfonyl fluoride hydrochloride] were obtained from Boehringer-Mannheim (Indianapolis, IN, U.S.A.). Goat anti-mouse $\mathrm{IgG}\left(\mathrm{Fab}^{\prime}\right)_{2}$ fragment conjugated to indocarbocyanine was from Jackson ImmunoResearch Laboratories (West Grove, PA, U.S.A.) . Mouse IgG was obtained from Vector Laboratories (Burlingame,
CA, U.S.A.). Tissue culture supplies were purchased from Corning Glass Works (Corning, NY, U.S.A.). Powdered Dulbecco's modified Eagle's medium and fetal calf serum were obtained from GIBCO (Grand Island, NY, U.S.A.). Human SH-SY5Y neuroblastoma cells were obtained from Dr. June Biedler (Sloan Kettering Institute, New York, NY, U.S.A.). Monoclonal anti-clathrin heavy chain antibody (X22) was a generous gift from Dr. Frances Brodsky (University of California, San Francisco, CA, U.S.A.).

\section{Cell culture conditions}

For studies of $\mathrm{mAChR}$ sequestration and phosphoinositide turnover, human SH-SY5Y cells (passage nos. 68-76) were routinely grown in tissue culture flasks $\left(75 \mathrm{~cm}^{2} / 250 \mathrm{ml}\right)$ in $20 \mathrm{ml}$ of Dulbecco's modified Eagle's medium supplemented with $10 \%$ (by volume) fetal calf serum. Cells were grown for 7-14 days at $37^{\circ} \mathrm{C}$ in an atmosphere consisting of $10 \%$ $\mathrm{CO}_{2}$ and $90 \%$ humidified air. Cells were isolated after aspiration of the medium and incubation with a modified Pucks $D_{1}$ solution (Honegger and Richelson, 1976). For immunocytochemical studies, SH-SY5Y cells were grown on glass coverslips ( $22 \mathrm{~mm}$ in diameter) for $48 \mathrm{~h}$, during which time $20-30 \%$ confluency was achieved.

\section{Subcellular fractionation}

A modified procedure of the method of Strader et al. (1984) was used. Ten to 20 flasks of SH-SY5Y cells were detached and resuspended in buffer A $(142 \mathrm{mM} \mathrm{NaCl}, 5.6$ $\mathrm{m} M \mathrm{KCl}, 2.2 \mathrm{~m} M \mathrm{CaCl}_{2}, 3.6 \mathrm{~m} M \mathrm{NaHCO}_{3}, 1 \mathrm{~m} M \mathrm{MgCl}_{2}$, $5.6 \mathrm{~m} M$ D-glucose, and $30 \mathrm{~m} M$ HEPES, $\mathrm{pH} 7.4$ ), and 5-ml aliquots of cells were incubated for $30 \mathrm{~min}$ at $37^{\circ} \mathrm{C}$ in the presence or absence of agonist under the conditions defined (hypertonicity, $\mathrm{K}^{+}{ }_{i}$ depletion, etc.). Reactions were terminated by addition of $30 \mathrm{ml}$ of ice-cold buffer $\mathrm{A}$, and cells were centrifuged at $300 \mathrm{~g}$ for $3 \mathrm{~min}$ at $4^{\circ} \mathrm{C}$. Supernatants were aspirated, and cell pellets were resuspended in ice-cold buffer A ( - glucose) that contained $2.5 \mathrm{mg} / \mathrm{ml}$ of concanavalin A. Cells were left on ice for $20 \mathrm{~min}$ and recentrifuged at $300 \mathrm{~g}$ for $3 \mathrm{~min}$. Cell pellets were then hypotonically lysed by gentle homogenization in $10 \mathrm{ml}$ of TE buffer $[10 \mathrm{~m} M$ Tris-HCl (pH 7.4), $2 \mathrm{~m} M$ EDTA, $2 \mu \mathrm{g} / \mathrm{ml}$ of aprotinin, 1 $\mu \mathrm{g} / \mathrm{ml}$ of leupeptin, $0.7 \mu \mathrm{g} / \mathrm{ml}$ of pepstatin, and $1 \mathrm{~m} M$ Pefabloc]. Lysates were then centrifuged at $30,000 \mathrm{~g}$ for 10 min to obtain a crude plasma membrane $\left(\mathrm{P}_{\mathrm{l}}\right)$ fraction. The supernatants were then centrifuged at $200,000 \mathrm{~g}$ for $90 \mathrm{~min}$ to obtain a "light" membrane $\left(\mathrm{V}_{1}\right)$ fraction.

\section{Radioligand binding}

Agonist-induced sequestration of $\mathrm{mAChRs}$ was monitored as the loss of $\left[{ }^{3} \mathrm{H}\right]$ NMS binding sites on intact SH-SY5Y cells, as previously described (Thompson and Fisher, 1990; Slowiejko et al., 1994). After exposure of cells to Oxo-M, the agonist was removed by washing, and aliquots of cells were then incubated with either $6 \mathrm{n} M\left[{ }^{3} \mathrm{H}\right] \mathrm{NMS}$ in buffer A for $18 \mathrm{~h}$ at $4^{\circ} \mathrm{C}$ or, alternatively, with $1 \mathrm{n} M\left[{ }^{3} \mathrm{H}\right] \mathrm{QNB}$ in buffer A for $90 \mathrm{~min}$ at $37^{\circ} \mathrm{C}$. Subcellular fractions of $\mathrm{SH}$ SY5Y cells were resuspended in KGEH buffer $(139 \mathrm{mM}$ potassium glutamate, $4 \mathrm{mM} \mathrm{MgCl}, 10 \mathrm{~m} M$ EGTA, and $30 \mathrm{~m} M$ HEPES, pH 7.4), a buffer that approximates the intracellular milieu, before radioligand binding. The low temperature used for $\left[{ }^{3} \mathrm{H}\right]$ NMS assays ensures that the recycling of mAChRs to plasma membrane is prevented (Thompson and Fisher, 1991). Nonspecific binding was determined as that unaffected by inclusion of $25 \mu M$ atropine. Reactions were rapidly terminated by filtration through Whatman GF/ 
B glass fiber filters, and radioactivity was determined after addition of $5 \mathrm{ml}$ of Universol scintillation fluid.

\section{Immunoprecipitation of $\mathrm{mAChR}$ subtypes}

The proportion of $m A C h R$ subtypes present in the $V_{1}$ fraction was determined by the procedures previously described (Slowiejko et al., 1994).

\section{Measurement of cytoplasmic $\mathrm{Ca}^{2+}$ concentration $\left(\left[\mathrm{Ca}^{2+}\right]_{i}\right)$ \\ Basal and Oxo-M-stimulated values for $\left[\mathrm{Ca}^{2+}\right]_{i}$ in $\mathrm{SH}-$ SY5Y cells were determined by monitoring fura-2 fluores- cence in a Shimadzu model RF-5000 spectrofluorophoto- meter using the dual wavelength method, as previously de- scribed (Thompson et al., 1991).}

\section{Measurement of cytoplasmic pH}

Intracellular $\mathrm{pH}$ was monitored using the membrane-permeant fluorescent probe BCECF-AM (Rink et al., 1982). Cell suspensions were incubated with the probe $(4 \mu M)$ in buffer $\mathrm{A}$ for $30 \mathrm{~min}$ at $37^{\circ} \mathrm{C}$. The cells were then washed free of the extracellular probe and transferred to the cuvette compartment of a dual wavelength computer-controlled spectrofluorimeter (SPEX, Edison, NJ, U.S.A.). The fluorescence intensity was monitored as the ratio of excitation intensity at $505 \mathrm{~nm}$ relative to that at $439 \mathrm{~nm}$ (isobestic point ). Emission was monitored at $530 \mathrm{~nm}$. The absence of dye leakage was confirmed during experiments by addition of an anti-fluorescein rabbit IgG antibody to the cuvette. Calibration of the intracellular fluorescein spectra was obtained by equilibration of the extracellular and intracellular $\mathrm{pH}$ with $4 \mu M$ nigericin in high-potassium $(142 \mathrm{~m} M$ ) buffer A to eliminate potential gradients across cellular membranes (Thomas et al., 1979).

\section{Measurement of phosphoinositide turnover}

SH-SY5Y cells were allowed to prelabel for 3 days in Dulbecco's modified Eagle's medium/fetal calf serum containing $10 \mu \mathrm{Ci} / \mathrm{ml}$ of $\left[{ }^{3} \mathrm{H}\right]$ inositol. Cells were then detached and washed with buffer A. Following the experimental manipulations, the accumulation of a total radiolabeled inositol phosphate fraction $\left({ }^{3} \mathrm{H}-\mathrm{IP}_{\mathrm{T}}\right)$ observed in the presence or $\mathrm{ab}-$ sence of $1 \mathrm{~m} M$ Oxo-M was monitored during a 30-min incubation in the presence of $\mathrm{Li}^{+}$, as described previously (Thompson and Fisher, 1990).

\section{Measurement of $I(\mathbf{1 , 4 , 5}) \mathrm{P}_{\mathbf{3}}$ mass}

The mass of $\mathrm{I}(1,4,5) \mathrm{P}_{3}$ was quantified essentially as previously described (Palmer et al., 1994). Aliquots of SHSY5Y cells $(\sim 1 \mathrm{mg}$ of protein) were incubated in $0.5 \mathrm{ml}$ of buffer $\mathrm{A}$ at $37^{\circ} \mathrm{C}$ in the presence or absence of $1 \mathrm{mM}$ Oxo-M. Reactions were terminated by addition of $0.5 \mathrm{ml}$ of ice-cold 20\% (wt/vol) trichloroacetic acid. The trichloroacetic acid extracts were first neutralized with water-saturated diethyl ether. Aliquots of neutralized extracts (Fisher et al., 1990 ) were then incubated in $10 \mathrm{~m} M$ Tris- $\mathrm{HCl}, 1 \mathrm{~m} M$ EDTA, and $0.1 \mathrm{~m} M \beta$-mercaptoethanol ( $\mathrm{pH} 8.8$ ) for $15 \mathrm{~min}$ at $4^{\circ} \mathrm{C}$ with a rat cerebellar membrane preparation $(400 \mu \mathrm{g}$ of protein ) in the presence of $0.01 \mu \mathrm{Ci}$ of $\left[{ }^{3} \mathrm{H}\right] \mathrm{I}(1,4,5) \mathrm{P}_{3}$. Standards $\left[0-10\right.$ pmol of $\left.\mathrm{I}(1,4,5) \mathrm{P}_{3}\right]$ were assayed concurrently. Bound radioligand was separated from free radioligand by rapid vacuum filtration (at $4^{\circ} \mathrm{C}$ ) through Whatman GF/B glass fiber filters. Protein content was measured by the method of Geiger and Bessman (1972).

\section{Immunofluorescence}

Human SH-SY5Y neuroblastoma cells were grown on glass coverslips in six-well plates for $48 \mathrm{~h}$ and then subjected to the experimental protocols indicated in the figure legends. At the end of each experimental protocol, the cells were fixed for $30 \mathrm{~min}$ at room temperature in $3.5 \%(\mathrm{wt} / \mathrm{vol})$ paraformaldehyde in $0.1 M$ phosphate-buffered saline (PBS), pH 7.4. Cells were rinsed with PBS twice and then

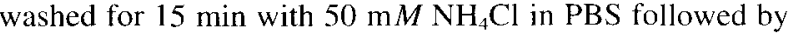
two additional washes in PBS. The cells were then permeabilized with $0.04 \%$ (wt/vol) saponin in PBS for $15 \mathrm{~min}$ at room temperature and then blocked with $1 \%(\mathrm{wt} / \mathrm{vol})$ bovine serum albumin in PBS for $30 \mathrm{~min}$. The primary antibody was applied onto the coverslips $(100 \mu \mathrm{l})$ at a concentration of $5 \mu \mathrm{g} / \mathrm{ml}$ (anti-heavy chain clathrin; X-22) and incubated overnight at $4^{\circ} \mathrm{C}$. After four washes ( $10 \mathrm{~min}$ each) with PBS, the cells were incubated with $100 \mu \mathrm{l}$ of goat anti-mouse IgG conjugated to indocarbocyanine $(1: 200)$ for $60 \mathrm{~min}$ at room temperature. Coverslips were then washed four times ( 10 min each ) and mounted on glass slides with $p$-phenylenediamine in $75 \%$ glycerol $/ 25 \%$ PBS. Immunofluorescence was observed by conventional and confocal fluorescence microscopy (Bio-Rad model MRC 600) with an argon-krypton laser and a tetramethyl rhodamine filter.

\section{Data analysis}

Results given are mean \pm SEM values for the number (n) of separate experiments performed. Student's two-tailed $t$ tests were used to evaluate the statistical differences of the means of paired or unpaired sets of data.

\section{RESULTS}

\section{Hypertonicity inhibits agonist-induced $\mathrm{mAChR}$ sequestration}

The extent of agonist-induced sequestration of mAChRs and of stimulated phosphoinositide hydrolysis was monitored under isotonic ( $325 \mathrm{mOsm}$ ) or hypertonic conditions (Fig. 1). Incubation of SH-SY5Y cells in buffer A made hypertonic by supplementation with either sucrose or $\mathrm{NaCl}$ impaired $\mathrm{mAChR}$ sequestration as a function of osmolarity. For example, after the cells had been exposed to Oxo-M for $30 \mathrm{~min}$ under hypertonic conditions ( $550 \mathrm{mOsm}), \sim 70-80 \%$ fewer $\left[{ }^{3} \mathrm{H}\right] \mathrm{NMS}$ binding sites were lost from the cell surface than from agonist-treated cells incubated in isotonic buffer A. Although complete inhibition of $\mathrm{mAChR}$ sequestration was observed at $\sim 650 \mathrm{mOsm}$, the lower value of $550 \mathrm{mOsm}$ was routinely used to minimize any significant change in cell volume (see, for example, Bowen and Morgan, 1988). To determine the effect of an increase in osmolarity on $\mathrm{mAChR}$-stimulated phosphoinositide hydrolysis, the accumulation of ${ }^{3} \mathrm{H}$ $\mathrm{IP}_{\mathrm{T}}$ was monitored over a 30 -min incubation period. The mAChR-stimulated inositol lipid hydrolysis was much less inhibited under hypertonic conditions than was receptor sequestration $(\sim 20-25 \%$ at $550 \mathrm{mOsm})$. Because the activation of MAChRs in SH-SY5Y cells elicits two kinetically distinct phases of mAChR-stimulated phosphoinositide hydrolysis (Fisher et al., 1994; Wojcikiewicz et al., 1994), the effect of hypertonicity on initial receptor responses was also monitored. When 


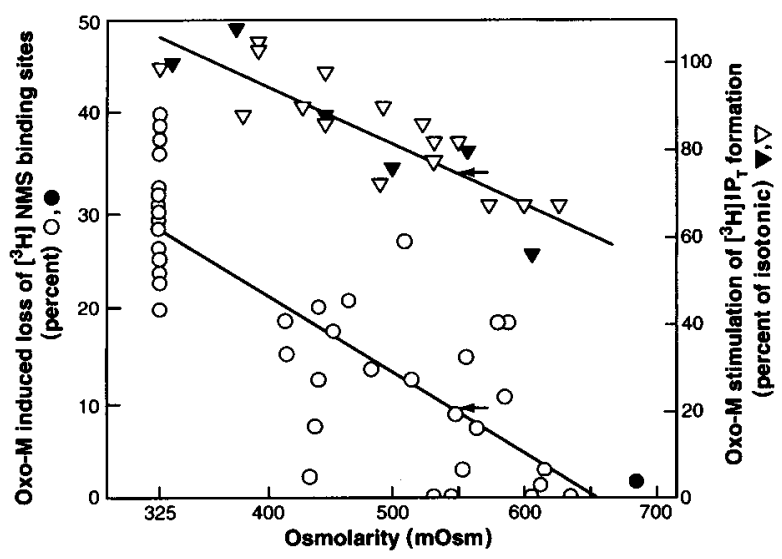

FIG. 1. The ability of Oxo-M to induce a loss of $\left[{ }^{3} \mathrm{H}\right] \mathrm{NMS}$ binding sites is reduced under conditions of hyperosmolarity. SH-SY5Y, cells $\left(\sim 1 \mathrm{mg}\right.$ of protein) were preincubated at $37^{\circ} \mathrm{C}$ for $20 \mathrm{~min}$ in either buffer $\mathrm{A}$ alone (isotonic; $325 \mathrm{mOsm}$ ) or with buffer $\mathrm{A}$ made hypertonic by addition of either sucrose $(O)$ or $\mathrm{NaCl}(\bullet)$ at the osmolarity indicated. Osmolarity was determined using an Osmette osmometer (Precision Systems, Sudbury, MA, U.S.A.). To each group of cells was then added Oxo-M (final concentration, $1 \mathrm{mM}$ ), and reactions were allowed to proceed for a further $30 \mathrm{~min}$ at $37^{\circ} \mathrm{C}$. Reactions were terminated, and the amount of $\left[{ }^{3} \mathrm{H}\right]$ NMS specifically bound was then determined as described in Materials and Methods. When incubated in isotonic buffer $A$ in the absence of agonist, specific $\left[{ }^{3} \mathrm{H}\right]$ NMS binding was $\sim 300$ $\mathrm{fmol} / \mathrm{mg}$ of protein. Hypertonicity had no detectable effect on $\left[{ }^{3} \mathrm{H}\right]$ NMS binding in the absence of OxO-M. In the presence of Oxo-M, $30-40 \%$ of $\mathrm{mAChRs}$ were sequestered under isotonic conditions ( $325 \mathrm{mOsm})$. Under the same experimental conditions, the ability of Oxo-M to stimulate the formation of ${ }^{3} \mathrm{H}-\mathrm{IP}_{\mathrm{T}}$ was determined under either conditions of isotonicity or hypertonicity [sucrose $(\nabla)$ or $\mathrm{NaCl}(\boldsymbol{\nabla})$ added]. Radioactivity associated with the ${ }^{3} \mathrm{H}-\mathrm{IP}_{\mathrm{T}}$ fraction under basal and $\mathrm{OxO}-\mathrm{M}$-stimulated conditions was $\sim 15$ and $240 \times 10^{3} \mathrm{dpm} / \mathrm{mg}$ of protein, respectively. Hypertonicity had no effect on ${ }^{3} \mathrm{H}-\mathrm{IP}$ formation under basal conditions. For both $\left[{ }^{3} \mathrm{H}\right] \mathrm{NMS}$ and ${ }^{3} \mathrm{H}-\mathrm{IP}_{\mathrm{T}}$ level measurements, results shown are from individual experiments, and lines represent linear regression analyses. The arrows $\rightarrow$ ) indicate the hypertonic conditions chosen for subsequent experiments (550 mOsm).

$\mathrm{I}(1,4,5) \mathrm{P}_{3}$ formation was monitored after $10 \mathrm{~s}$ of agonist addition, comparable increases were observed for cells incubated in isotonic and hypertonic ( $550 \mathrm{mOsm})$ buffer A (Fig. 2A), whereas a small reduction in the Oxo-M-mediated rise in $\left[\mathrm{Ca}^{2+}\right]_{i}$ was observed in hypertonically treated cells, when compared with cells incubated under isotonic conditions $(\sim 25 \%$; Fig. $2 \mathrm{~B})$. Taken together, these results indicate that incubation of SH-SY5Y cells in hypertonic buffer A results in a more pronounced inhibition of $\mathrm{mAChR}$ sequestration than of phosphoinositide hydrolysis, regardless of whether the latter is monitored under conditions of acute or prolonged agonist exposure.

\section{Kinetics of $\mathrm{mAChR}$ sequestration under hypertonic conditions}

When cells were incubated in isotonic buffer A, $\mathrm{mAChR}$ sequestration was time dependent with the onset occurring within 5 min of Oxo-M addition, and

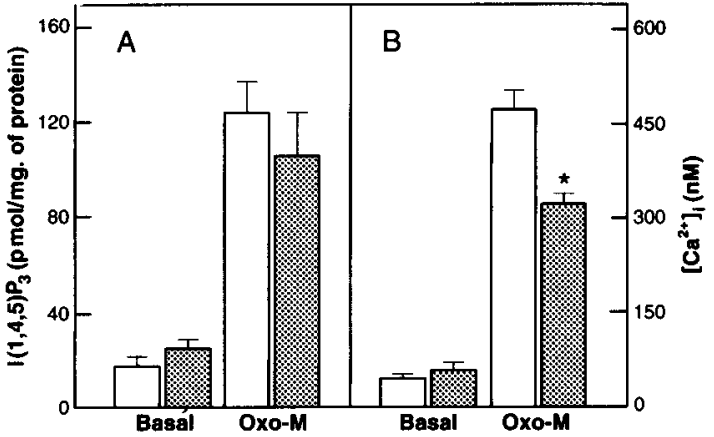

FIG. 2. Effect of hypertonicity on (A) basal and Oxo-M-stimulated $\mathrm{I}(1,4,5) \mathrm{P}_{3}$ formation and $(\mathrm{B})$ basal and OxO-M-stimulated rise in $\left[\mathrm{Ca}^{2+}\right]_{\mathrm{i}}$. SH-SY5Y cells were preincubated for $20 \mathrm{~min}$ at $37^{\circ} \mathrm{C}$ in either the presence of isotonic buffer $A(\square)$ or buffer $A$ made hypertonic with sucrose (圈; 550 mOsm). Cells were then incubated in the absence or presence of $1 \mathrm{mM}$ Oxo-M, and basal and stimulated concentrations of $I(1,4,5) P_{3}$ were determined after $10 \mathrm{~s}$ of agonist addition (A). In $\mathrm{B}$, both basal and maximal increases in $\left[\mathrm{Ca}^{2+}\right]_{\text {i }}$ observed in the presence of Oxo$M$ were monitored. A maximal increase in $\left[\mathrm{Ca}^{2+}\right]_{\text {, was observed }}$ $\sim 10-15 \mathrm{~s}$ after Oxo-M addition. Data are mean \pm SEM (bars) values $\left(n=4\right.$ and 20 for $1(1,4,5) P_{3}$ level and $\left[\mathrm{Ca}^{2+}\right]_{i}$ measurements, respectively). ${ }^{\star} p<0.05$ for difference from isotonic value.

the maximal effect observed after 30-60 min (Fig. $3 \mathrm{~A})$. In contrast, little or no loss of $\left[{ }^{3} \mathrm{H}\right] \mathrm{NMS}$ binding sites was observed at any time point for agonist-treated cells when incubated in hypertonic buffer A (550

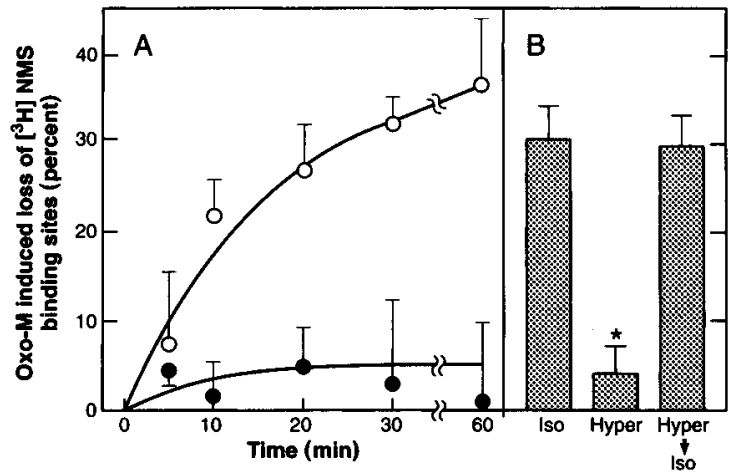

FIG. 3. Time course and reversibility of the inhibition of Oxo-Minduced loss of $\left[{ }^{3} \mathrm{H}\right] \mathrm{NMS}$ binding sites observed under hypertonic conditions. A: SH-SY5Y cells were preincubated for $20 \mathrm{~min}$ in either the presence of isotonic buffer $A(O)$ or buffer $A$ plus sucrose $(\bullet ; 550 \mathrm{mOsm})$. After the preincubation period, Oxo-M (final concentration, $1 \mathrm{mM}$ ) was added to each set of incubation mixtures, and reactions were allowed to proceed for the times indicated. B: In a separate series of experiments, $\mathrm{SH}-\mathrm{SY} 5 \mathrm{Y}$ cells were preincubated for $20 \mathrm{~min}$ in either isotonic or hypertonic buffer $A$, as detailed above. The hypertonically treated cells were then divided into two aliquots, one of which was centrifuged and resuspended in isotonic buffer $A$ (Hyper $\rightarrow$ Iso), whereas the other aliquot was resuspended in hypertonic buffer $A$ and allowed to incubate for $30 \mathrm{~min}$ at $37^{\circ} \mathrm{C}$. Oxo-M $(1 \mathrm{mM})$ was then added to each set of incubations, and reactions were allowed to proceed for $30 \mathrm{~min}$ at $37^{\circ} \mathrm{C}$. Results for both $\mathrm{A}$ and $\mathrm{B}$ are mean \pm SEM (bars) values for three or four separate experiments. ${ }^{*} p$ $<0.05$ for difference from isotonic buffer $A$ value. 


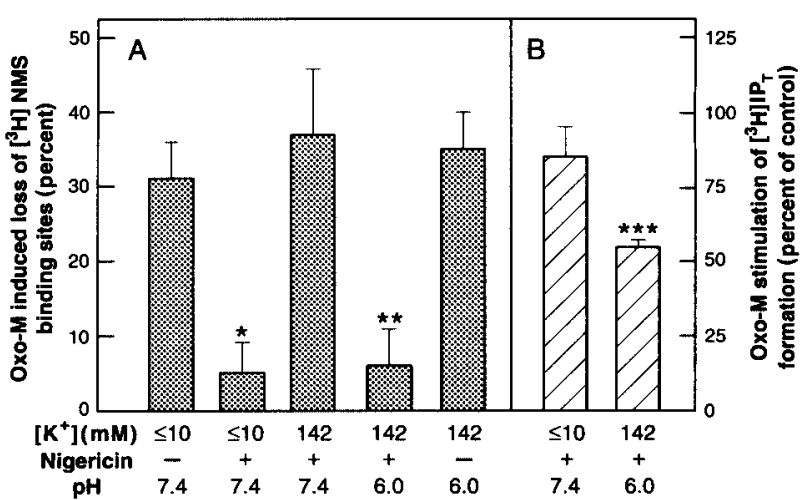

FIG. 4. Depletion of $\mathrm{K}^{+}$, or acidification of cytosol blocks agonist-induced mAChR sequestration. A: SH-SY5Y cells $(\sim 1 \mathrm{mg}$ of protein) were preincubated for 40 (for depletion of $\mathrm{K}^{+}$) or 10 min (for acidification of cytosol) in the absence or presence of $4 \mu M$ nigericin and in the presence of the $\left[\mathrm{K}^{+}\right]$and buffer $\mathrm{A}$ at the $\mathrm{pH}$ values indicated. When the $\left[\mathrm{K}^{+}\right]$was increased to 142 $\mathrm{mM}$, the $[\mathrm{NaCl}]$ was reduced to $5.5 \mathrm{mM}$ to maintain isotonicity. After preincubation, Oxo-M was added (final concentration, 1 $\mathrm{mM}$ ), and reactions were allowed to proceed for a further 30 min. B: Cells prelabeled with $\left[{ }^{3} \mathrm{H}\right.$ ] inositol were first preincubated under conditions outlined above, and then the release of a ${ }^{3} \mathrm{H}$ $\mathrm{IP}_{\mathrm{T}}$ fraction was monitored in the presence of $1 \mathrm{mM}$ Oxo-M over a 30-min incubation period. Values are expressed as ${ }^{3} \mathrm{H}$ $I P_{T}$ formation relative to controls (incubated in the absence of nigericin). In the absence of the ionophore, values for both basal and $\mathrm{O} \times \mathrm{O}-\mathrm{M}$-stimuled ${ }^{3} \mathrm{H}-\mathrm{IP}$ formation obtained in the presence of either high $\left[\mathrm{K}^{+}\right.$] or low $\mathrm{pH}$ were comparable to those observed in the presence of buffer $\mathrm{A}(\mathrm{pH} 7.4)$. Data are mean \pm SEM (bars) values for four or five separate experiments. ${ }^{*} p<0.05$ different from the control ( - nigericin); ${ }^{*} p<0.05$, different from $142 \mathrm{mMK}^{+}, \mathrm{pH} 7.4 ;^{\star \star \star} p<0.05$, different from the corresponding control ( - nigericin).

mOsm). The inhibitory effects of hypertonicity on mAChR sequestration were readily reversible. Thus, when cells that had been preincubated in hypertonic buffer $\mathrm{A}$ for $20 \mathrm{~min}$ were transferred to isotonic buffer A for $30 \mathrm{~min}$, the extent of agonist-induced $\mathrm{mAChR}$ sequestration was comparable to that observed for cells incubated continuously in isotonic buffer A ( $29 \pm 4$ vs. $31 \pm 4 \%$, respectively; $n=3$; Fig. $3 \mathrm{~B}$ ).

\section{Depletion of $\mathrm{K}^{+}{ }_{\mathrm{i}}$ or acidification of the cytosol inhibits $\mathrm{mAChR}$ sequestration}

Nigericin, an ionophore that promotes electroneutral $\mathrm{K}^{+} / \mathrm{H}^{+}$exchange, has previously been used to manipulate $\left[\mathrm{K}^{+}\right]_{\mathrm{i}}$ (Larkin et al., 1985) and cytoplasmic $\mathrm{pH}$ (Hansen et al., 1993). Incubation of SH-SY5Y cells in buffer A containing 5 or $10 \mathrm{mM} \mathrm{K} \mathrm{K}^{+}$in the presence of $4 \mu M$ nigericin resulted in $>80 \%$ inhibition of mAChR sequestration (Fig. 4A). Under these conditions, the $\mathrm{K}^{+}$content of the cells was reduced by $>85 \%(2.53 \pm 0.3$ and $0.32 \pm 0.07 \mu \mathrm{Eq} / \mathrm{mg}$ of protein in the absence and presence of nigericin, respectively; $\mathrm{n}=4)$. When the extracellular $\left[\mathrm{K}^{+}\right]$was increased to $142 \mathrm{~m} M$ (a concentration that approximates the intracellular concentration of the cation ), inclusion of nigericin had no effect on the extent of the Oxo-Minduced loss of $\left[{ }^{3} \mathrm{H}\right] \mathrm{NMS}$ binding sites. Under condi- tions in which the $\left[\mathrm{K}^{+}\right]$is equivalent on both sides of the plasma membrane, nigericin can be used to clamp the intracellular $\mathrm{pH}$ at the $\mathrm{pH}$ of the extracellular buffer (Thomas et al., 1979). When SH-SY5Y cells were incubated with $4 \mu M$ nigericin in the presence of 142 $\mathrm{m} M \mathrm{~K}^{+}$, but at a reduced $\mathrm{pH}(6.0), \mathrm{mAChR}$ sequestration was inhibited by $>85 \%$ (Fig. $4 \mathrm{~A}$ ). Incubation of $\mathrm{SH}-\mathrm{SY} 5 \mathrm{Y}$ cells at $\mathrm{pH} 6.0$, in the absence of nigericin, did not inhibit mAChR sequestration. Direct measurement of the cytoplasmic $\mathrm{pH}$ revealed that the latter was reduced from 7.5 to 6.4 under these conditions. Depletion of $\mathrm{K}^{+}{ }_{i}$ had little or no effect on mAChRstimulated inositol lipid hydrolysis as monitored by either the accumulation of ${ }^{3} \mathrm{H}-\mathrm{IP}$ or $\mathrm{I}(1,4,5) \mathrm{P}_{3}$ formation (Figs. $4 \mathrm{~B}$ and $5 \mathrm{~A}$ ), whereas an increase in both basal and Oxo-M-stimulated $\left[\mathrm{Ca}^{2+}\right]_{\mathrm{i}}$ was observed under these conditions (Fig. 5B). In contrast, acidification of the cytosol resulted in a significant inhibition $(\sim 45 \%)$ of Oxo-M stimulated ${ }^{3} \mathrm{H}-\mathrm{IP}_{\mathrm{T}}$ formation (Fig. 4B).

\section{Agonist-induced subcellular redistribution of cell surface mAChRs under conditions of hypertonicity or depletion of $\mathrm{K}^{+}{ }_{\mathrm{i}}$}

The agonist-induced redistribution of cell surface mAChRs in SH-SY5Y cells, and its modulation by hypertonicity and depletion of $\mathrm{K}^{+}{ }_{\mathrm{i}}$, was also monitored by means of subcellular fractionation. In preliminary studies, an Oxo-M-induced redistribution of mAChRs from a dense to less dense fraction $[35 / 60 \%$ to $0 /$ $35 \%$ sucrose interfaces (see Lohse et al., 1990)] was observed when cell lysates were subjected to sucrose density gradient fractionation. However, because of the limited degree of enrichment of mAChRs in this less dense fraction (less than twofold over the control), alternative approaches were sought. Better resolution was obtained when crude plasma membrane $\left(P_{1}\right)$ and

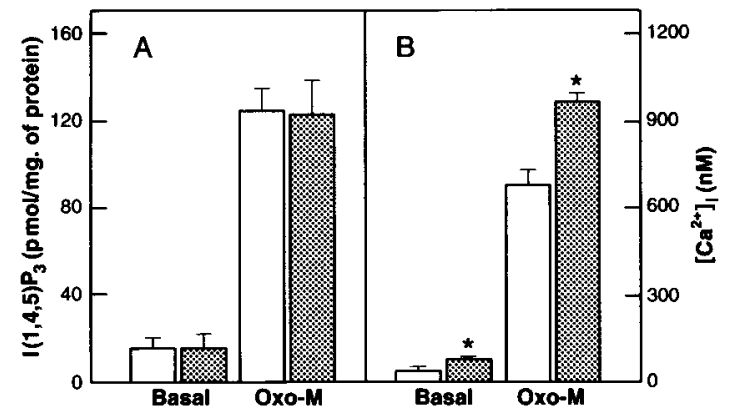

FIG. 5. Effect of depletion of $\mathrm{K}^{+}{ }_{\mathrm{i}}$ on $(\mathbf{A})$ basal and Oxo-M-stimulated $\mathrm{I}(1,4,5) \mathrm{P}_{3}$ formation and $(\mathbf{B})$ basal and Oxo-M-stimulated rise in $\left[\mathrm{Ca}^{2+}\right]_{\mathrm{i}}$. SH-SY5Y cells were preincubated in buffer $\mathrm{A}(5.6$ $\mathrm{mMK}$ ) for $20 \mathrm{~min}$ at $37^{\circ} \mathrm{C}$ in either the absence $(\square)$ or presence (圈) of $4 \mu M$ nigericin. After preincubation, Oxo-M was added (final concentration, $1 \mathrm{mM}$ ), and reactions were allowed to proceed for a further $10 \mathrm{~s}$ for $1(1,4,5) \mathrm{P}_{3}$ determination or $10-15 \mathrm{~s}$ to monitor the maximal rise in $\left[\mathrm{Ca}^{2+}\right]$. Data are mean \pm SEM (bars) values $\left(n=4\right.$ and 15 for $l(1,4,5) P_{3}$ level and $\left[\mathrm{Ca}^{2+}\right]_{i}$ measurements, respectively). ${ }^{*} p<0.05$, different from the control (- nigericin). 
TABLE 1. Subcellular distribution of mAChRs in control and Oxo-M-stimulated cells

\begin{tabular}{|c|c|c|c|}
\hline & Intact cells & $\begin{array}{c}P_{1} \\
(30,000 \mathrm{~g} / 10 \mathrm{~min})\end{array}$ & $\frac{V_{1}}{(200,000 \mathrm{~g} / 90 \mathrm{~min})}$ \\
\hline \multicolumn{4}{|l|}{ Control } \\
\hline$\left[{ }^{3} \mathrm{H}\right]$ QNB binding: specific activity (fmol/mg of protein) & $333 \pm 34$ & $859 \pm 96$ & $88 \pm 33$ \\
\hline Distribution of recovered $\left[{ }^{3} \mathrm{H}\right] \mathrm{QNB}$ sites $(\%)$ & $(100)$ & $95 \pm 7$ & $5 \pm 1$ \\
\hline$\left[{ }^{3} \mathrm{H}\right] \mathrm{NMS}$ binding: specific activity ( $\mathrm{fmol} / \mathrm{mg}$ of protein) & $339 \pm 41$ & $826 \pm 111$ & $42 \pm 11^{a}$ \\
\hline Distribution of recovered $\left[{ }^{3} \mathrm{H}\right] \mathrm{NMS}$ sites $(\%)$ & (100) & $97 \pm 5$ & $3 \pm 0^{a}$ \\
\hline Distribution of cellular protein $(\%)$ & $(100)$ & $35 \pm 6$ & $19 \pm 3$ \\
\hline \multicolumn{4}{|l|}{ Oxo-M } \\
\hline$\left[{ }^{3} \mathrm{H}\right] \mathrm{QNB}$ binding: specific activity (fmol/mg of protein) & $306 \pm 33^{b}$ & $704 \pm 94^{b}$ & $352 \pm 77^{h}$ \\
\hline Distribution of recovered $\left[{ }^{3} \mathrm{H}\right] \mathrm{QNB}$ sites $(\%)$ & $(100)$ & $79 \pm 7^{b}$ & $21 \pm 3^{b}$ \\
\hline$\left[{ }^{3} \mathrm{H}\right] \mathrm{NMS}$ binding: specific activity (fmol/mg of protein) & $201 \pm 23^{b}$ & $573 \pm 84^{b}$ & $85 \pm 20^{a, b}$ \\
\hline Distribution of recovered $\left[{ }^{3} \mathrm{H}\right] \mathrm{NMS}$ sites $(\%)$ & $(100)$ & $93 \pm 5^{\prime \prime}$ & $7 \pm 1^{a, b}$ \\
\hline Distribution of cellular protein $(\%)$ & $(100)$ & $30 \pm 6$ & $19 \pm 2$ \\
\hline
\end{tabular}

SH-SY5Y cells were incubated in the absence or presence of $1 \mathrm{~m} M$ Oxo-M for 30 min and then hypotonically lysed, and crude plasma membrane $\left(P_{1}\right)$ and "light" membrane $\left(V_{1}\right)$ fractions were obtained by differential centrifugation, as described in Materials and Methods. Intact cells and $\mathrm{P}_{1}$ and $\mathrm{V}_{1}$ fractions were assayed for $\left[{ }^{3} \mathrm{H}\right] \mathrm{QNB}$ or $\left[{ }^{3} \mathrm{H}\right] \mathrm{NMS}$ binding and for protein content. The concentrations of both radioligands were sufficient to occupy $>90 \%$ of $\mathrm{mAChR}$ sites in the subcellular fractions. Data are mean \pm SEM values for five to seven separate experiments. The overall recoveries of $\left[{ }^{3} \mathrm{H}\right] \mathrm{QNB}$ and $\left[{ }^{3} \mathrm{H}\right] \mathrm{NMS}$ binding sites ranged from 77 to $87 \%$. Approximately $40 \%$ of the cellular protein was recovered in the supernatants.

"Different from $\left[{ }^{3} \mathrm{H}\right] \mathrm{QNB}$ binding data, $p<0.05$.

${ }^{b}$ Different from control cell binding data, $p<0.05$ (matched-pair analysis).

"light membrane", $\left(\mathrm{V}_{1}\right)$ fractions were isolated from hypotonic lysates of SH-SY5Y cells by means of differential centrifugation (Table 1). In control cells, 95$97 \%$ of $\mathrm{mAChRs}$ were recovered in the $\mathrm{P}_{1}$ fraction and only $3-5 \%$ of receptors in the $\mathrm{V}_{1}$ fraction. Whereas $\left[{ }^{3} \mathrm{H}\right] \mathrm{QNB}$ and $\left[{ }^{3} \mathrm{H}\right] \mathrm{NMS}$ labeled the same number of binding sites in both the intact cells and the $P_{1}$ fraction, consistently more mAChR sites were labeled by the lipophilic antagonist $\left[{ }^{3} \mathrm{H}\right] \mathrm{QNB}$ in the $\mathrm{V}_{1}$ fraction than by the hydrophilic antagonist, $\left[{ }^{3} \mathrm{H}\right] \mathrm{NMS}(p<0.05)$. When SH-SY5Y cells were incubated in the presence of $1 \mathrm{~m} M$ Oxo-M for $30 \mathrm{~min}$, the distribution of mAChRs was altered such that receptor density was reduced in both intact cells and $P_{1}$ fractions, but the effect was more pronounced for $\left[{ }^{3} \mathrm{H}\right] \mathrm{NMS}(31-41 \%)$ than for $\left[{ }^{3} \mathrm{H}\right] \mathrm{QNB}$ binding $(8-18 \%)$. Conversely, a marked increase in $\mathrm{mAChR}$ density was observed for the $V_{1}$ fraction, such that after a 30-min exposure of SH-SY5Y cells to Oxo-M, the number of $\left[{ }^{3} \mathrm{H}\right] \mathrm{QNB}$ binding sites recovered in this fraction increased to $420 \%$ of control values. This translocation of mAChRs could be blocked by prior incubation of the cells with $5 \mu M$ NMS (Fig. 6). As observed for control cells, $m A C h R s$ present in the $V_{1}$ fraction obtained from OxoM-treated cells were much less accessible to the hydrophilic ligand $\left[{ }^{3} \mathrm{H}\right] \mathrm{NMS}$ ( $233 \%$ of control), and no further increase in the number of $\left[{ }^{3} \mathrm{H}\right] \mathrm{NMS}$ binding sites could be obtained when the assays were conducted at either higher ligand concentrations or at $37^{\circ} \mathrm{C}$ (data not shown). Because SH-SY5Y cells express predominantly (but not exclusively) mAChRs of the $\mathrm{m}_{3}$ subtype (Slowiejko et al., 1994), immunoprecipitation studies were conducted on the $V_{1}$ fraction. Antisera to the $m_{3}, m_{2}$, and $m_{1} \mathrm{mAChRs}$ precipitated 77 $\pm 11,20 \pm 10$, and $3 \pm 3 \%$ of binding sites $(n=3)$. These results indicate that on agonist addition, $\mathrm{m}_{3}$ $\mathrm{mAChRs}$ undergo endocytosis and are increasingly recovered in a "light" membrane fraction. The mAChRs in this fraction are readily detected by lipophilic antagonists such as $\left[{ }^{3} \mathrm{H}\right]$ QNB (or $\left[{ }^{3} \mathrm{H}\right]$ scopolamine) but are relatively inaccessible to $\left[{ }^{3} \mathrm{H}\right] \mathrm{NMS}$.

The Oxo-M-induced redistribution of $\mathrm{mAChRs}$ into the $V_{1}$ fraction was markedly inhibited $(>85 \%)$ when SH-SY5Y cells were incubated under hypertonic conditions. The inhibitory effect of hypertonicity could be reversed if cells pretreated under hypertonic conditions were transferred to isotonic buffer $\mathrm{A}$ before addition of Oxo-M (Fig. 6). Depletion of $\mathrm{K}^{+}{ }_{i}$ also inhibited the redistribution of $\mathrm{mAChRs}$ by $>85 \%$. When $\mathrm{SH}-$ SY5Y cells were incubated with pilocarpine, a partial muscarinic agonist, fewer $\left[{ }^{3} \mathrm{H}\right] \mathrm{QNB}$ binding sites were recovered in the $V_{1}$ fraction than were observed for Oxo-M ( 159 vs. $420 \%$ of control values, respectively), a result consistent with the limited ability of this agonist to promote a loss of [ $\left.{ }^{3} \mathrm{H}\right] \mathrm{NMS}$ sites (Thompson and Fisher, 1990; Slowiejko et al., 1994) (Fig. 6).

\section{Cellular redistribution of clathrin in SH-SY5Y cells in response to hypertonicity, depletion of $\mathrm{K}^{+}{ }_{\mathrm{i}}$, or acidification of cytosol}

Indirect immunoffuorescence together with conventional and confocal microscopy was used to confirm that the experimental conditions chosen, i.e., hypertonicity, depletion of $\mathrm{K}^{+}{ }_{i}$, or acidification of cytosol had resulted in a cellular redistribution of clathrin in $\mathrm{SH}$ SY5Y cells. Anti-clathrin immunofluorescence in control cells appeared to be distributed throughout the cytoplasm in a punctate manner, with some accumula- 


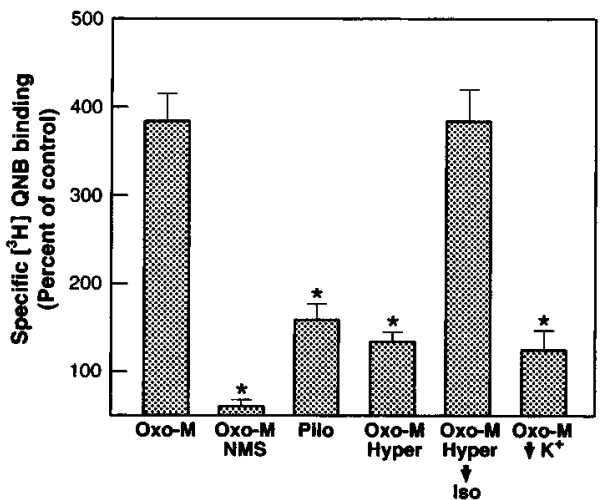

FIG. 6. Effect of hypertonicity and depletion of $\mathrm{K}^{+}$on the subcellular redistribution of mAChRs. SH-SY5Y cells were first incubated with either buffer $\mathrm{A}$ (control) or $1 \mathrm{mM}$ Oxo-M or pilocarpine (Pilo) for $30 \mathrm{~min}$ at $37^{\circ} \mathrm{C}$. Cells were then hypotonically lysed, and ' $\mathrm{V}$ ' ' fractions were obtained by means of subcellular fractionation, as described in Materials and Methods. The density of mAChRs in $V_{1}$ fractions was then determined by means of $\left[{ }^{3} \mathrm{H}\right]$ QNB binding. In some experiments, SH-SY5Y cells were either preincubated with $5 \mu \mathrm{MNMS}$ or, alternatively, subjected to conditions of hypertonicity or depletion of $\mathrm{K}^{+}$, before addition of Oxo-M (for details, see legends to Figs. 3 and 4). Results are expressed as specific binding relative to controls that were incubated in the absence of agonist. Neither hypertonicity nor depletion of $\mathrm{K}^{+}$, had any significant effect on $\left[{ }^{3} \mathrm{H}\right]$ QNB binding in $\mathrm{V}_{1}$ fractions obtained from control cells. The ability of NMS preincubation to reduce $\left[{ }^{3} \mathrm{H}\right]$ QNB binding to below control levels may reflect the ability of the antagonist to inhibit constitutive cycling of mAChRs. Data are mean \pm SEM (bars) values for three to eight separate experiments. ${ }^{*} p<0.05$, different from Oxo-M alone.

tion in the perinuclear region (Fig. 7A). The presence of clathrin at the plasma membrane itself was difficult to resolve consistently owing to a low steady-state concentration. Little or no immunofluorescence was observed when cells were incubated with mouse nonspecific IgG (Fig. 7B). Under hyperosmolar conditions, the perinuclear accumulation of clathrin was markedly enhanced, and this was accompanied by an apparent reduction in the amount of clathrin present in the cytoplasm. This pattern of clathrin redistribution is consistent with previous studies of nonneural cells (Doxsey et al., 1987; Heuser and Anderson, 1989; Hansen et al., 1993) and has been interpreted to indicate a disruption of the assembly of clathrin-coated pits. The redistribution of clathrin from cytosol to perinuclear region observed under hyperosmolar conditions was reversed when cells were returned to isotonic buffer A (Fig. 7D). Increased immunostaining of clathrin in the perinuclear region was also observed in cells depleted of $\mathrm{K}^{+}{ }_{i}$ (Fig. 7E). Under conditions in which the cytosol was acidified, an increased occurrence of microaggregates of clathrin throughout the cytoplasm and at the plasma membrane was apparent (Fig. 7F). However, in contrast to the redistribution pattern observed for hypertonicity and depletion of $\mathrm{K}^{+}$, an accumulation of clathrin in the perinuclear region was not observed when the cytosol was acidified. This pattern of immu- nostaining is consistent with the known ability of reduced $\mathrm{pH}$ to inhibit the budding of clathrin-coated vesicles from the plasma membrane (Sandvig et al., 1987). None of the three experimental procedures adversely affected the morphology of SH-SY5Y cells.

\section{Neither activation of protein kinase $\mathrm{C}$ nor perturbation of plasma membrane cholesterol inhibits $\mathrm{mAChR}$ sequestration}

The possible involvement of caveolae, non-clathrincoated membrane invaginations, in the internalization of mAChRs was investigated by monitoring the extent of loss of $\left[{ }^{3} \mathrm{H}\right] \mathrm{NMS}$ binding sites after activation of protein kinase $\mathrm{C}$ or following the perturbation of plasma membrane cholesterol. Under the latter two conditions, the functioning of caveolae is reported to be inhibited (Rothberg et al., 1990; Schnitzer et al., 1994; Smart et al., 1994). Preincubation of SH-SY5Y cells with $1 \mu M$ PMA before addition of Oxo-M had little or no effect on the extent of $m A C h R$ sequestration ( $35 \pm 2$ vs. $29 \pm 4 \%$ loss of $\left[{ }^{3} \mathrm{H}\right] \mathrm{NMS}$ sites for control and PMA-treated cells, respectively; $n=5-9$ ). In contrast, Oxo-M-stimulated ${ }^{3} \mathrm{H}-\mathrm{IP}_{\mathrm{T}}$ formation was inhibited by $\sim 50 \%$ by PMA (data not shown). Overnight incubation of the cells with $1 \mu M$ PMA also failed to modulate the extent of $\mathrm{MAChR}$ internalization. Neither preincubation of SH-SY5Y cells with digitonin, a steroid glycoside that targets the plasma membrane owing to its high cholesterol content, nor the addition of nystatin, a polyene antibiotic that binds cholesterol, significantly reduced the magnitude of loss of $\left[{ }^{3} \mathrm{H}\right] \mathrm{NMS}$ binding sites following Oxo-M addition ( $37 \pm 5$ and $36 \pm 3 \%$ for $5 \mu M$ digitonin and nystatin, respectively; $\mathrm{n}=3$ ).

\section{DISCUSSION}

Substantial evidence has accumulated to implicate clathrin in the mechanism underlying receptor internalization based on the repeated demonstration that the endocytosis of receptor-specific ligands is markedly inhibited when cells are incubated under conditions of hypertonicity, depletion of $\mathrm{K}^{+}$, or acidification of cytosol. By application of one or more of these conditions, a clathrin-mediated mechanism has previously been identified for the endocytosis of constitutively active receptors, e.g., transferrin, low-density lipoprotein, or asialoglycoprotein (Larkin et al., 1986; Sandvig et al., 1987; Oka et al., 1989) and for the epidermal growth factor receptor (Sandvig et al., 1987). Although less extensively studied, a role for clathrin in the endocytosis of $\beta_{2}$-adrenergic receptors and $\mathrm{m}_{4}$ mAChRs has been proposed based on inhibition by hypertonicity and depletion of $\mathrm{K}^{+}$, respectively ( $\mathrm{Yu}$ et al., 1993; Maloteaux and Hermans, 1994). However, whether PLC-linked receptors are endocytosed in a similar manner is currently unknown. In the present study, evidence is presented that all three experimental conditions, namely, hypertonicity, depletion of $\mathrm{K}^{+}{ }_{i}$, or 

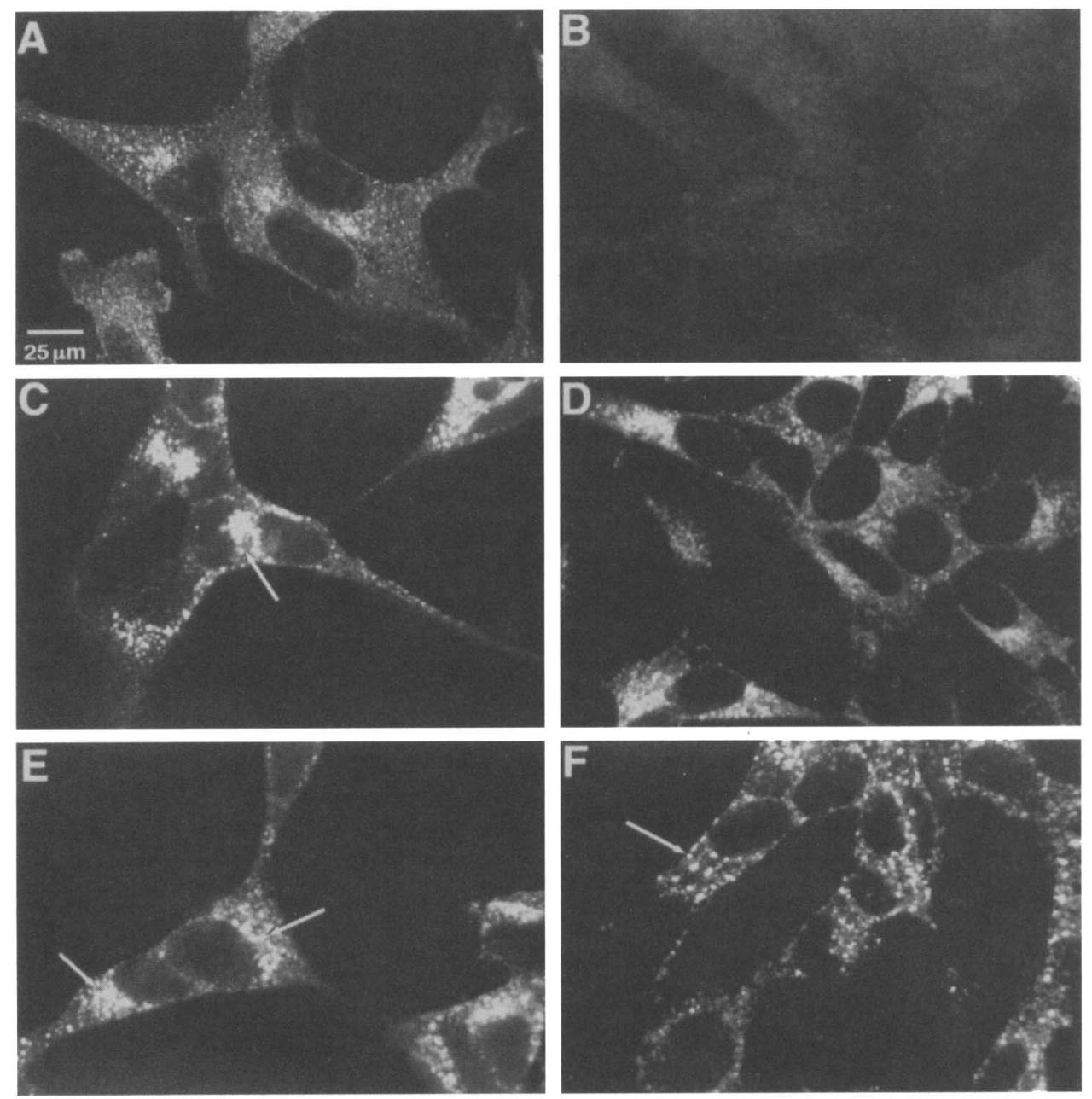

FIG. 7. Indirect immunofluorescence localization of clathrin in human neuroblastoma cells viewed by confocal microscopy. In control experiments, $\mathrm{SH}-\mathrm{SY} 5 \mathrm{Y}$ cells were incubated for $20 \mathrm{~min}$ at $37^{\circ} \mathrm{C}$ in buffer A before formaldehyde fixation, permeabilization, and incubation with either monoclonal anticlathrin $\mathrm{lgG}(X-22 ; 5 \mu \mathrm{g} / \mathrm{ml}$; A) or mouse nonspecific $\mathrm{lgG}$ (from Vector Laboratories; $5 \mu \mathrm{g} / \mathrm{ml}$; B), respectively. Note the punctate distribution of clathrin throughout the cytoplasm and accumulation in the perinuclear region in $\mathrm{A}$. C: Redistribution of clathrin following a 20-min incubation in buffer A made hypertonic with sucrose (550 mOsm). Enhanced accumulation of clathrin in the perinuclear region of the cell is indicated by the arrow. D: Reversibility of effect when hypertonically treated SH-SY5Y cells were transferred to isotonic buffer $\mathrm{A}$ for $30 \mathrm{~min}$ before fixation. E: Cells depleted of $\mathrm{K}$, by incubation with $4 \mu M$ nigericin for 40 min in the presence of $5.5 \mathrm{mM} \mathrm{K}$. Note the enhanced accumulation of clathrin in the perinuclear region, as indicated by the arrows. F: Cells acidified by incubation with $4 \mu \mathrm{M}$ nigericin for $10 \mathrm{~min}$ at $37^{\circ} \mathrm{C}$ in the presence of $142 \mathrm{mM} \mathrm{K}(\mathrm{pH} 6.0)$. Aggregation of clathrin is indicated by the arrow. Shown are confocal images of $1-\mu \mathrm{m}$ optical slices taken midway through the cell(s). Bar in $\mathrm{A}=25 \mu \mathrm{m}$.

acidification of the cytosol result in a marked attenuation of the internalization of the $\mathrm{m}_{3} \mathrm{mAChRs}$, a phosphoinositide-linked receptor. Agonist-induced sequestration of mAChRs in SH-SY5Y cells was inhibited in proportion to the degree of hyperosmolarity, with maximal inhibition observed at $\sim 600$ mOsm, a value similar to that necessary for complete inhibition of transferrin endocytosis in reticulocytes (Bowen and Morgan, 1988). Furthermore, inhibition of $\mathrm{mAChR}$ sequestration, like that of transferrin endocytosis, could be reversed when cells were returned to an isotonic medium. Incubation of SH-SY5Y cells with nigericin, in the presence of low concentrations of extracellular $\mathrm{K}^{+}(5-10 \mathrm{~m} M)$, resulted in a marked
$(>85 \%$ ) inhibition of $\mathrm{mAChR}$ sequestration. That this inhibition resulted from a depletion of $\mathrm{K}^{+}$can be inferred from the reduction in $\mathrm{K}^{+}$content of cells incubated in the presence of nigericin and from the inability of the ionophore to inhibit sequestration when intraand extracellular concentrations of $\mathrm{K}^{+}$approximated each other. When nigericin was used to lower cytosolic $\mathrm{pH}$ to that of the extracellular buffer (6.0), agonistinduced $\mathrm{mAChR}$ sequestration was also markedly inhibited. Taken collectively, these results indicate that when clathrin distribution is disrupted, the internalization of $\mathrm{mAChRs}$ is concurrently inhibited.

A redistribution of clathrin in SH-SY5Y cells, as determined by indirect immunofluorescence, accompa- 
nied the reductions in agonist-induced sequestration. Thus, in control SH-SY5Y cells, a punctate distribution of clathrin was observed throughout the cytoplasm, with some accumulation in the perinuclear region of the cell. Hypertonicity and depletion of $\mathrm{K}^{+}{ }_{\mathrm{i}}$ resulted in a more pronounced accumulation of clathrin in the perinuclear region with a reduction in clathrin immunoreactivity in the cytoplasm. This distribution pattern observed for clathrin in SH-SY5Y cells under control and experimental conditions was similar to that obtained previously for nonneural cells (Doxsey et al., 1987; Heuser and Anderson, 1989; Hansen et al., 1993). Clathrin-coated vesicles, which are formed at both the plasma membrane and trans-Golgi network, derive from a common pool of cytosolic clathrin (Pley and Parham, 1993). The increased immunostaining of clathrin in the perinuclear region of SH-SY5Y cells under conditions of hypertonicity or depletion of $\mathrm{K}^{+}{ }_{\mathrm{i}}$ is consistent with an accumulation of clathrin-coated vesicles in the trans-Golgi network. This, in turn, may result in a reduction in the availability of clathrin for assembly into clathrin-coated pits at the plasma membrane. In contrast, when the cytosol was acidified, there was an appearance of microaggregates of clathrin within the cytoplasm and at the cell surface, but little or no increased perinuclear staining was observed. This pattern of immunostaining is consistent with the known ability of acidification of the cytosol to inhibit the budding of clathrin-coated pits (Sandvig et al., 1987).

Although mAChR sequestration was attenuated under conditions of hypertonicity, depletion of $\mathrm{K}^{+}$, or acidification of cytosol, no comparable inhibition of the agonist-mediated generation of inositol phosphates and rise in $\left[\mathrm{Ca}^{2+}\right]_{i}$ was observed. In addition, given that cell surface rather than internalized $\mathrm{mAChRs}$ preferentially couple to PLC activation (Thompson and Fisher, 1991), it should be noted that inhibition of mAChR sequestration was not accompanied by any measurable increase in the extent of phosphoinositide hydrolysis. The latter result indicates that the number of $\mathrm{mAChRs}$ present at the plasma membrane is not the sole determinant of the magnitude of stimulated inositol lipid turnover (see Fisher et al., 1994). The failure of hypertonicity and depletion of $\mathrm{K}^{+}{ }_{i}$ to affect adversely PLC activation excludes the possibility that the inhibition of $\mathrm{mAChR}$ sequestration results from either nonspecific interference with receptor-ligand interactions or, alternatively, is due to cell toxicity. Of the three experimental paradigms used, only acidification of the cytosol resulted in a significant inhibition of stimulated phosphoinositide hydrolysis, a result that may reflect the pH optimum of PLC (Rhee et al., 1989) or a reduction in ATP availability (Sandvig et al., 1987). However, even under these conditions, stimulated inositol lipid hydrolysis was less inhibited than $\mathrm{mAChR}$ internalization. Other studies have indicated that the experimental procedures used to perturb clathrin distribution do not inhibit fluid-phase endocytosis (Daukas and Zigmond, 1985; Heuser and Ander- son, 1989; Oka et al., 1989) or endocytosis mediated via non-clathrin-coated membrane invaginations (Roettger et al., 1995).

Although it has been proposed that receptor sequestration may represent an altered conformation of the receptor within the plasma membrane (Wang et al., 1989), two lines of evidence support the concept that mAChRs in SH-SY5Y cells undergo endocytosis. First, on agonist addition, $\mathrm{mAChRs}$ are recovered in a "light" membrane fraction, distinct from that of the plasma membrane, when lysates of SH-SY5Y cells are subjected to subcellular fractionation. It is likely that this fraction represents an "endosomal" compartment of the cell that in part, at least, may be derived from vesicles from which the clathrin coat has previously been removed. Thus, mAChRs that may initially enter the cell via clathrin-coated pits are recovered in this fraction on prolonged agonist exposure. The mAChRs in this fraction are accessible to lipophilic, but not hydrophilic, ligands, suggesting that they are present in endocytic "inside-out" vesicles. This redistribution of receptors can be blocked by hypertonicity or depletion of $\mathrm{K}^{+}{ }_{\mathrm{i}}$. Second, in digitonin-permeabilized cells, the sequestered mAChRs also remain inaccessible to the hydrophilic ligands, even under conditions of prolonged incubation. Only when the concentration of digitonin is further increased are these "occluded" receptor sites unmasked (Slowiejko et al., 1994). Taken collectively, these results and those obtained under conditions in which clathrin distribution is perturbed suggest that on agonist addition, mAChRs in $\mathrm{SH}-$ SY $5 Y$ cells undergo endocytosis via a clathrin-mediated process. However, conclusive proof of such will necessitate the direct demonstration of $\mathrm{mAChRs}$ in clathrin-coated pits. In this regard, it is relevant to note that the presence of mAChRs in a brain subcellular fraction enriched in clathrin-coated vesicles has previously been documented (Silva et al., 1986). In addition, $\mathrm{GABA}_{\mathrm{A}}$ /benzodiazepine receptors have also been localized to clathrin-coated vesicles (Tehrani and Barnes, 1993). Based on immunocytochemical evidence, a role for clathrin in the internalization of substance $P$ receptors (which couple to phosphoinositide turnover) has also recently been proposed (Garland et al., 1994). Thus, it is conceivable that an involvement of clathrin in the endocytosis of PLC-linked receptors may be widespread.

Recently, a role for caveolae in cell signaling events has been proposed, based principally on the localization of the plasma membrane $\mathrm{Ca}^{2+}$ pump, $\mathrm{I}(1,4,5) \mathrm{P}_{3}$ receptor protein, and the endothelin receptor to these structures (Fujimoto, 1993; Fujimoto et al., 1993; Chun et al., 1994). However, a major involvement of caveolae in the internalization of mAChRs in SHSY5Y cells appears unlikely for the following reasons. First, cholesterol perturbation and activation of protein kinase $\mathrm{C}$, both of which have been demonstrated to interfere with the structure and function of caveolae (Rothberg et al., 1990; Schnitzer et al., 1994; Smart 
et al., 1994), had no effect on the Oxo-M-induced loss of $\left[{ }^{3} \mathrm{H}\right] \mathrm{NMS}$ sites. Second, caveolae are reported to be unaffected by hypertonicity and depletion of $\mathrm{K}^{+}{ }_{\mathrm{i}}$ (Roettger et al., 1995), conditions under which mAChR sequestration is blocked.

In summary, the agonist-induced internalization of mAChRs in SH-SY5Y neuroblastoma is inhibited under conditions in which clathrin distribution is perturbed. These results are consistent with the occurrence of a clathrin-mediated endocytosis of mAChRs in these cells.

Acknowledgment: The authors wish to thank Dr. Anne Heacock for her helpful comments, Dr. Rebecca Van Dyke for assistance with the measurements of cytoplasmic $\mathrm{pH}$, Noel Badyna for technical assistance, and Ms. Jo Ann Kelsch for preparation of the manuscript. This work was supported by NIH grant NS 23831 and NIMH grant MH 46252 (to S.K.F.) and NIDDK grant DK-34933 (to the Michigan Gastrointestinal Peptide Research Center) (to S.A.E.). D.M.S. was supported by NIH training grant GM 07767.

\section{REFERENCES}

Anderson R. G. W. (1993) Caveolae: where incoming and outgoing messengers meet. Proc. Natl. Acad. Sci. USA 90, 10909 - 10913.

Bowen B. J. and Morgan E. H. (1988) Effect of osmolar and ionic composition of the extracellular fluid on transferrin endocytosis and exocytosis and iron uptake by reticulocytes. J. Cell. Physiol. 134, 1-12.

Chun M., Liyanage U. K., Lisanti M. P., and Lodish H. F. (1994) Signal transduction of a $G$ protein-coupled receptor in caveolae: colocalization of endothein and its receptor with caveolin. Proc. Natl. Acad. Sci. USA 91, 11728-11732.

Daukas G. and Zigmond S. H. (1985) Inhibition of receptor-mediated but non fluid-phase endocytosis in polymorphonuclear leukocytes. J. Cell Biol. 101, 1673-1679.

Doxsey S. J., Brodsky F. M., Blank G. A., and Helenius A. (1987) Inhibition of endocytosis by anti-clathrin antibodies. Cell 50, $453-463$.

Fisher S. K. (1995) Homologous and heterologous regulation of receptor-stimulated phosphoinositide hydrolysis. Eur. J. Pharmacol. 288, 231-250.

Fisher S. K., Heacock A. M., Seguin E. B., and Agranoff B. W. (1990) Polyphosphoinositides are the major source of inositol phosphates in carbamoylcholine-stimulated SK-N-SH neuroblastoma cells. Mol. Pharmacol. 38, 54-63.

Fisher S. K., Slowiejko D. M., and McEwen E. L. (1994) A rapid attenuation of muscarinic agonist stimulated phosphoinositide hydrolysis precedes receptor sequestration in human SH-SY5Y neuroblastoma cells. Neurochem. Res. 19, 549-554.

Fujimoto T. ( 1993 ) Calcium pump of the plasma membrane is localized in caveolae. J. Cell Biol. 120, 1147-1157.

Fujimoto T. S., Nakade S., Miyawaki A., Mikoshiba K., and Ogawa Z. ( 1993 ) Localization of inositol 1,4,5-trisphosphate receptorlike protein in plasmalemmal caveolae. J. Cell Biol. 119, 15071513.

Garland A. M., Grady E. F., Payan D. G., Vigna S. R., and Bunnett N. W. (1994) Agonist-induced internalization of the substance $\mathrm{P}\left(\mathrm{NK}_{1}\right)$ receptor expressed in epithelial cells. Biochem. J. 303, $177-186$.

Geiger P. J. and Bessman S. P. (1972) Protein determination by Lowry's method in the presence of sulfhydryl reagents. Anal. Biochem. 49, 467-474.

Hansen S., Sandvig K., and van Deurs B. (1993) Clathrin and HA2 adaptors: effects of potassium depletion, hypertonic medium, and cytosol acidification. J. Cell Biol. 121, 61-72.
Harden T. K., Petch L. A., Traynelis S. F., and Waldo G. L. (1985) Agonist-induced alteration in the membrane form of muscarinic cholinergic receptors. J. Biol. Chem. 260, 13060-13066.

Hausdorff W. P., Caron M. G., and Lefkowitz R. J. (1990) Turning off the signal: desensitization of $\beta$-adrenergic receptor function. FASEB J. 4, 2881-2889.

Heuser J. E. and Anderson R. G. W. ( 1989 ) Hypertonic media inhibit receptor-mediated endocytosis by blocking clathrin-coated pit formation. J. Cell Biol. 108, 389-400.

Honegger P. and Richelson E. (1976) Biochemical differentiation of mechanically dissociated mammalian brain in aggregating cell culture. Brain Res. 109, 335-354.

Larkin J. M., Donzell W. C., and Anderson R. G. W. ( 1985 ) Modulation of intracellular potassium and ATP: effects on coated pit function in fibroblasts and hepatocytes. J. Cell. Physiol. 124, $372-378$.

Larkin J. M., Donzel] W. C., and Anderson R. G. W. (1986) Potassium-dependent assembly of coated pits: new coated pits form as planar clathrin lattices. J. Cell Biol. 103, 2619-2627.

Lohse J., Benovic L., Caron M. G., and Lefkowitz R. J. (1990) Multiple pathways of rapid $\beta_{2}$-adrenergic receptor desensitization. J. Biol. Chem. 265, 3202-3209.

Maloteaux J. M. and Hermans E. (1994) Agonist-induced muscarinic cholinergic receptor internalization, recycling and degradation in cultured neuronal cells. Biochem. Pharmacol. 47, 7788.

Oka J. A., Christensen M. D., and Weigel P. H. ( 1989) Hyperosmolarity inhibits galactosyl receptor-mediated but not fluid phase endocytosis in isolated rat hepatocytes. J. Biol. Chem. 264, $12016-12024$.

Palmer R. K., Yule D. 1., McEwen E. L., Williams J. A., and Fisher S. K. (1994) Agonist-specific calcium signaling and phosphoinositide hydrolysis in human SK-N-MCIXC neuroepithelioma cells. J. Neurochem. 63, 2099-2107.

Pley U. and Parham P. (1993) Clathrin: its role in receptor-mediated vesicular transport and specialized functions in neurons. Crit. Rev. Biochem. Mol. Biol. 28, 431-464.

Rhee S. G., Suh P.-G., Ryu S.-H., and Lee S. Y. (1989) Studies of inositol phospholipid-specific phospholipase C. Science 255, $546-550$.

Rink T. J., Tsien R. Y., and Pozzan T. (1982) Cytoplasmic pH and free $\mathrm{Mg}^{2+}$ in lymphocytes. J. Cell Biol. 95, 189- 195.

Roettger B. F., Rentsch R. U., Pinon D., Holicky E., Hadac E., Larkin J. M., and Miller L. J. ( 1995 ) Dual pathways of internalization of the cholecystokinin receptor. J. Cell Biol. 128, 10291041 .

Rothberg K. G., Ying Y.-S., Kamen B. A., and Anderson R. G. W. (1990) Cholesterol controls the clustering of the glycophospholipid-anchored membrane receptor for 5-methyltetrahydrofolate. J. Cell Biol. 111, 2931-2938.

Sadée W., Yu V. C., Richard M. L., Preis P. N., Schwat M. R., Brodsky F. M., and Biedler J. L. (1987) Expression of neurotransmitter receptors and $m y c$ proto-oncogenes in subclones of a human neuroblastoma cell line. Cancer Res. 47, 5207-5212.

Sandvig K., Olsnes S., Petersen O. W., and van Deurs B. (1987) Acidification of the cytosol inhibits endocytosis from coated pits. J. Cell Biol. 105, 679-689.

Schnitzer J. E., Oh P., Pinney E., and Allard J. (1994) Filipinsensitive caveolae-mediated transport in endothelium: reduced transcytosis, scavenger endocytosis, and capillary permeability of select macromolecules. J. Cell Biol. 127, 1217-1232.

Silva W. I., Andres A., Schook W., and Puszkin S. (1986) Evidence for the presence of muscarinic acetylcholine receptors in bovine brain coated vesicles. J. Biol. Chem. 261, 14788-14796.

Slowiejko D. M., Levey A. I., and Fisher S. K. (1994) Sequestration of muscarinic cholinergic receptors in permeabilized neuroblastoma cells. J. Neurochem. 62, 1795-1803.

Slowiejko D. M., McEwen E. L., Ernst S. A., and Fisher S. K. (1995) Agonist-induced sequestration of muscarinic cholinergic receptors in human neuroblastoma cells: evidence for clathrin-mediated internalization. (Abstr.) Life Sci. 56, 1033. 
Smart E. J., Foster D. C., Ying Y.-S., Kamen B. A., and Anderson R. G. W. ( 1994 ) Protein kinase C activators inhibit receptormediated potocytosis by preventing internalization of caveolae. J. Cell Biol. 124, 307-313.

Strader C. D., Sibley D. R., and Lefkowitz R. J. (1984) Association of sequestered beta-adrenergic receptors with the plasma membrane: a novel mechanism for receptor down regulation. Life Sci. 35, $1601-1610$.

Tehrani M. H. J. and Barnes E. M. Jr. (1993) Identification of $\mathrm{GABA}_{\mathrm{A}}$ /benzodiazepine receptors on clathrin-coated vesicles from rat brain. J. Neurochem. 60, 1755-1761.

Thomas J. A., Buchsbaum R. N., Zimniak A., and Racker E. ( 1979 ) Intracellular pH measurements in Ehrlich's ascites tumor cells utilizing spectroscopic probes generated in situ. Biochemistry 18, 2210-2218.

Thompson A. K. and Fisher S. K. (1990) Relationship between agonist-induced muscarinic receptor loss and desensitization of stimulated phosphoinositide turnover in two neuroblastomas: methodological considerations. J. Pharmacol. Exp. Ther. 252, $744-752$

Thompson A. K. and Fisher S. K. (1991) Preferential coupling of cell surface muscarinic receptors to phosphoinositide hydrolysis in human neuroblastoma cells. J. Biol. Chem. 266, 5004-5010.

Thompson A. K., Mostafapour S. P., Denlinger L. C., Bleasdale J. E., and Fisher S. K. (1991) The aminosteroid U-73122 inhibits muscarinic receptor sequestration and phosphoinositide hydrolysis in SK-N-SH neuroblastoma cells. J. Biol. Chem. 266, $23856-23862$.

vonZastrow M. and Kobilka B. K. ( 1992 ) Ligand-regulated internalization and recycling of human $\beta_{2}$-adrenergic receptors between the plasma membrane and endosomes containing transferrin receptors. J. Biol. Chem. 267, 3530-3538.

Wang H.-Y., Berrios M., and Malbon C. C. (1989) Localization of $\beta$-adrenergic receptors in A431 cells in situ. Biochem. J. 263, $533-538$.

Wojcikiewicz R. J. H. Tobin A. B and Nahorski S. R. (1994) Muscarinic receptor-mediated inositol 1,4,5-trisphosphate formation in SH-SY5Y neuroblastoma cells is regulated acutely by cytosolic $\mathrm{Ca}^{2+}$ and by rapid desensitization. J. Neurochem. 63, $177-185$.

Yu S. S., Lefkowitz R. J., and Hausdorff W. P. ( 1993 ) $\beta$-Adrenergic receptor sequestration. J. Biol. Chem. 268, 337-341. 